\title{
Literature and Psychology in the Context of the Interaction of Social Sciences
}

\author{
Badegül Can Emir \\ Karadeniz Technical University, Trabzon, Turkey
}

Literature and psychology are two branches of science that study human soul. Psychology researches human behaviors and their causes while literature depicts human behavior through fiction. These two branches of social science studying human behavior are interrelated and mutually beneficial. And the basic building block of the correlation between literature and psychology is a literary work. Literary works study human beings and describe their inner world with all its aspects. The reason is that a literary work is at the same time a product of a certain psychological condition. A literary work supports psychology in terms of depicting human psychological conditions, as we see in the example of Dostoevsky's characters. At the same time, Jung noted, psychology also provides insights into literature by exploring mental processes. A literary work benefits from psychology in terms of successfully presenting characters, expressing their moods, and bringing the reader into the psychological dimension of human reality.Psychology and study of literature meet in their focus on phantasies, emotions and human soul. Thus there exists a two-way relationship based on mutual interaction between literature and psychology, in the form of evaluation of a literary work with the resources of psychology and obtaining psychological truths from a literary work. Academic Ismet Emre (2006, p. III) gave the following explanation of the relationship between the two disciplines:

Beside literature and psychology there is no other branch of science which is engaged so much in the study of the relationship between human body and soul with its contradictions and dilemmas, making efforts to define the relationship in terms of certain rules, to know the mysterious aspects of the human soul and its subconscious areas by means of long and detailed journeys: at the same time both branches have been struggling in their existence between arts and science for about a century.

In another paper where he again analyzes the psychology of Turkish literature Ismet Emre (2009, p. 351) says the following: 
Today we all know that Dostoevsky is one of the most important historical persons indispensable for psychology and that his texts are used as textbooks and reference books in the psychology departments. But the same thing is done by literature and the studies of literature - psychological data is used both by authors in the process of plotting the characters of their imaginary world and by literature researchers in their efforts to penetrate the inner world of the existent literary works; Sigmund Freud's and Karl Gustav Jung's texts are recommended for reading as reference books on the Bachelor's degree level.

These quotations make it quite clear that these two disciplines benefit from one another; however the research results show that the evaluation of literary works on the basis of scientific psychological data is more common.

Psychological elements will be present in literary works as long as humans are the theme of the texts. Literature psychology covers almost everything we want to know about literature, because literature is a product of mind. According to Jung (Freud, Jung and Adler, 1981, p. 53), it is obvious that since psychology explores mental processes it will also provide insights into literature; because the human mind is the source of all science and arts. Then how is psychological analysis made in a literary work? As it is well known, the literary critic Meyer Howard Abrams (1912-2015) identifies four main elements of literature: the text, its theme, the author and the reader (Abrams, 1953, p. 6-29; see also Çalışkan, 2012, p. 29). And these elements are addressed in the analysis of literature. Literary work research with psychologydata is focused on these elements identified by Abrams, however when we talk about psychology in literary works the author and readerfocused works are not the first thing that comes to mind. It is possible to say that this is caused by the formalist trends which have influenced literary works since mid-twentieth century. According to the formalists, the literary text itself is the material which is at the literary critic's disposal and which will make literature more consistent and objective in itself. The research which ignores this and focuses only on the author and reader will be far from scientific; it should focus also on the other two elements, namely on the work itself and the world it creates. Interpreting a literary work involves approaching its characters and events as if they could exist in real life and studying characters' emotions, thoughts and behaviors. Psychology is the most important platform on which this analysis can be done. Literary critics R. Wellek (1903-1995) and A. Warren (1899-1986) characterized psychological analysis in a literary work as "analyzing the author's personality, the way a certain literary work was made, the psychological types which are present in the literary works and the characteristics of their behavior, and finally the effect of literature 
on its readers"(Wellek ve Warren, 1983, p. 101). As it is seen psychological analyses in a literary text is made based on the four main elements mentioned by Abrams. The psychology-based study of literature aims more at studying the influence of social conditions on the emotions, thoughts and behaviors of the characters in the story or novel, the analysis of the characters' personalities, the process of a literarywork formation and the psychology of creativity. That is, to use a general expression, the study here is like what Ömer Solak (2014, p. 104) said in his work titled "Edebiyat Biliminin Disiplinlerarası Imkânlarl" (Interdisciplinary Capabilities of the Study of Literature): "From the literature standpoint, analyzing psychology based on the writer, poet and literary work is to look at it from a new perspective by providing practical data for it".

Although approaching literary works with the scientific data of psychology is the result of the 19th century positivism, the relationship between the two mentioned disciplines goes back to the Ancient Greeks. Psychological content in the works of literature was found in Plato and Aristotle's works. The first literary work with psychological content is believed to be one of the masterpieces of Japanese literature - Murasaki Shikibu's The Tale of Genji [Genji Monogatari, about 1010 $\mathrm{CE}]$ which is also accepted as the world's first novel. The novel gives clues to understanding Japan of that period, and the focus on Genji's emotions provides a lot of reality related to human emotions in general. Along with The Tale of Genji,the works of the Italian humanist Giovanni Boccaccio, who is considered the first story-writer and novelist, are the first samples of literature psychology (Writing a Psychology Literature Review, 2014). The beginning of literature psychology as a genre goes back to the English writers Samuel Richardson and Laurence Sterne and their novels: Pamela [or Virtue Rewarded, 1740] by S. Richardson and the introspective novel The Life and Opinions of Tristram Shandy, Gentleman by L. Sterne (Writing a Psychology Literature Review, 2014). As it is seen, even though the relationship between literature and psychology goes back to the earlier centuries, it really developed only in 20th century with Sigmund Freud's discoveries in the area of psychoanalysis. Psychological content in literary works covered a broad area of genres from poetry to short story, from novel to drama, however the most open exposition of the human mind can be seen in novels. According to Holland (1990, p. 34), Freud in his letter dated 15 October 1987 mentioned that he was trying to identify his father's jealousy and his mother's love as Oedipus complex and that he was studying the unconscious forces behind Shakespeare's writing of Hamlet. Thus Freud in his work titled Creative Writers and Day-Dreaming developed a powerful model for the literary process. According to that model writers are excited by wishes, their wishes are unconsciously enriched beginning from their childhood and are shaped in a literary form that can convince the audience. Using that model Freud wrote lengthy analyses of Leonardo 
Da Vinci's and Dostoevsky's works; he interpreted the dreams in Jensen's novel Gradiva and at the same time in this way he analyzed Hamlet-type characters. Based on that it can be said that a work of literature contains its author's psychological hypothesis. There was human psychology in the texts written before Freud as well; however those were the outcome of the authors' instinctive, vague acquisitions.

It is well known that literature is an important source of inspiration for the science of psychology which tries to explain human emotions, behaviors and mental processes from a scientific perspective. According to N. Holland (1990, p. 34), literature has played a significant role in Freud's discovery of psychoanalysis. It will not be wrong to say that psychologists benefit from the study of literature in their analysis of certain concepts, phenomena and theories (Nayk1, 2014, p. 9). Each and every literary character qualifies as a case for psychological study.

And we can safely affirm that Freud is the most obvious example of the connection between literature and psychology. For not only did he quote literature in his hypotheses (we know that Oedipus complex is named after a character from a work by famous ancient Greek writer Sophocles), but even now - many years after he died - many writers and poets are still inspired by his ideas.(Psikoloji Edebiyattır'dan Edebiyatta Psikoloji'ye, 2014)

Not only S. Freud (1856-1939) did psychological studies related to literature, literary works and literary critics; studies in this area were done after him by other leading psychologists. Among them, there can be mentioned: Alfred Adler (18701937), C. Gustav Jung (1875-1961), Jacques Lacan (1901-1981), Erich Fromm (1900-1980), Wilhelm Reich (1897-1957), Otto Rank (1884-1939), Rollo May (1909-1994), and Melanie Klein (1882-1960). With his psychoanalytic literary criticism Freud opened the way which was followed by Jung's archetypal criticism, Lacan's structuralist psychoanalytic analysis and by other psychology theorists who continued to use various approaches to literary works thus making their input to the analysis of literary works.

Literary critics put as much effort as psychologists did to the study of the relationship between these two branches of science. It becomes especially obvious in the development of literature psychology in parallel to the development of the genre of novel. The "psychological" analyses in the Russian literature, especially in Dostoevsky's works, can be considered in this context. Raskolnikov's psychology in his Crime and Punishment [Prestupleniye i nakazaniye, 1866] and the psychology of the main character of his Idiot [Idiot, 1868] contains a lot of facts 
related to human nature. The Brothers Karamazov [Brat'ya Karamazovi, 1880] reveals the inner struggle between heart and mind in the context of religion. Virginia Woolf said (Urgan 2001, p. 61), "No European writer penetrates the dark depths of a human soul as deeply as Dostoevsky did." Leo Tolstoy explored human psychology as much as Dostoevsky did. War and Peace [Voyna i mir, 1869] questions the motives behind human behaviors. Anna Karenina [Anna Karenina, 1877] describes the characters with their inner worlds. Tolstoy's characters experience inner struggles, new understandings and disappointments as they fight for righteousness and justice. Many other literary critics and authors who contributed to literature psychology may be named, such as James Joyce, Henry James, Arthur Miller and Virginia Woolf. The Irish writer James Joyce, whom we know by his novel Ulysses [1922], is one of the important writers of the 20th century who described the depths of his characters' minds. James Joyce in his works focused on emotional and psychological processes in his characters' minds, depicting them with their thoughts, ambitions and phantasies. The American writer Henry James, whom we know by such works as The Turn of the Screw [1898] and Daisy Miller [1878], penetrates the minds of characters who find themselves in complicated situations. The writer focused in his works on the subject of human consciousness. In fact he was a brother of William James, one of the founders of functional psychology. The American writer Arthur Miller, whom we know by his play Death of a Salesman [1949], depicts his characters with their personal weaknesses, struggles and the inner world of their minds in different periods of their lives. The English feminist writer Virginia Woolf in her works such as The Voyage Out [1915], Night and Day [1919] and Mrs. Dalloway [1925] also penetrates the inner world of the characters and uses the stream of consciousness method in order to highlight the characters' psychological qualities. There are many other writers who have given attention to psychology in their literary studies. In her work titled Literary Studies and Psychology [Edebiyat Çalışmaları ve Psikoloji] Nil Korkut-Naykı made the following statement (2014, p. 9):

When talking about love we recall Shakespeare's Romeo and Juliet; when talking about jealousy we recall Othello; when talking about guilt and tormenting conscience we recall Dostoevsky's Raskolnikov; when talking about extreme ambition we recall Moby-Dick's Captain Ahab; when talking about betrayal we recall Shakespeare's Macbeth; when talking about loneliness and alienation we recall Kafka's Gregor Samsa who woke up one morning to find himself transformed into an insect or Camus's Mersault and many other literary characters. 
As a result we have the evidence of a mutually supportive two-way relationship between literature and psychology, as both psychologists and writers in their works often benefit from the interaction of these two areas of science. Especially the science of psychology provides literature psychology with more detailed and substantial information about a literary work which originates with the author as a part of the society and the author's social experiences.Based on the scientific findings of psychology, it studies the universe of the literary work and it sets on a journey to the inner world of the characters. It is clear that there is need a literature psychology in order to make a better analysis of a literary work. Despite the obvious need, except for some limited works, the area of literature psychology in the methodic sense has not yet been developed and is still remaining at the terminological level. Therefore it is necessary to provide literary psychology lessons in the university departments of literature and psychology in order to train specialists and to encourage research in this area. This will be an important step toward the goal of filling the existing gap in literature psychology. Such studies will open discussions about clear analogies between the study of literature and psychology making a contribution and setting a model for the newly developing researches in this area.

\section{References and notes:}

1. Abrams, M. H (1953). The Mirror and the Lamp: Romantic Theory and the Critical Tradition, New York: Oxford University Press.

2. Psikoloji Edebiyattır'dan Edebiyatta Psikoloji'ye (t.y). Taken from the following webpage on 11 August 2014:

http://www.biltek.tubitak.gov.tr/gelisim/psikoloji/deneme.htm

3. Çalışkan, Âdem (2012). "Edebiyat Teorisi Üzerine 3-Edebiyat Teorilerinin Sınıflandırılması”, Uluslararası Sosyal Araştırmalar Dergisi, 5 (21),24-60.

4. Emre, İsmet (2006). Edebiyat ve Psikoloji, Ankara: Anı Yayıncılık.

5. (2009). "Yeni Türk Edebiyatının Psikoloji Kaynakları", Turkish Studies, 4 (1), 319-355.

6. Freud, S., Jung, C. and Adler, A. (1981). Psikanaliz Açısından Edebiyat, (çev.: Selahattin Hilav), Dost Kitapevi Yayınlar1, Ankara,1981.

7. Holland, N. N. (1990). To Psychoanalytic Psychology and Literature-andPsychology, New York: Oxford Unıversity Press.

8. Writing a Psychology Literature Review.(t.y). Taken from the following webpage on 25 August 2014:

http://web.psych.washington.edu/writingcenter/writingguides/pdf/litrev.pdf

9. Naykı, Nil Korkut (2012). "Edebiyat Çalışmaları ve Psikoloji”, PIVOLKA, No 22, 9 -11 .

10. Solak, Ömer (2014). Edebiyat Biliminin Disiplinler arası Imkânlarl, Ankara: Pegem Akademi.

11. Urgan, Mina (2001). Virginia Woolf, 4. Baskı, İstanbul: Yapı Kredi Yayınları. 
12. Wellek Rene ve Warren Austin (1983), Edebiyat Biliminin Temelleri, (Çev.: Ahmet Edip Uysal), Ankara: Kültür ve Turizm Bakanlığı Yayınları.

\title{
Summary
}

\section{Literature and Psychology in the Context of the Interaction of Social Sciences}

\author{
Badegül Can Emir \\ Karadeniz Technical University, Trabzon, Turkey
}

There is a two-way relationship between literature and psychology coming together on the same intersection at the point of essential people and human behavior. As it is possible to approach literature and to evaluate literary works with the resources of psychology, and of literary sciences, so it is also possible to consider literary works based on psychology and to discover psychological facts in literature. Thus, both psychologists and writers have taken into consideration the relationship between literature and psychology. Studies of the science of psychology directed to literature, literary works and writers that was introduced by Freud continued with other outstanding theorists of psychology such as Adler, Jung, Lacan, Fromm, Reich and Klein. Likewise, writers and literary theorists such as N.Holland, Lev Tolstoy, Fyodor Dostoevsky and Virginia Woolf contributed to the psychology of literature. This paper is an effort to analyze the relationship between literature and psychology considering the wide field which the science of psychology opens for literature.

Keywords: Literature, Psychology,Psychologist, Literature Psychology, Interdisciplinary Studies. 